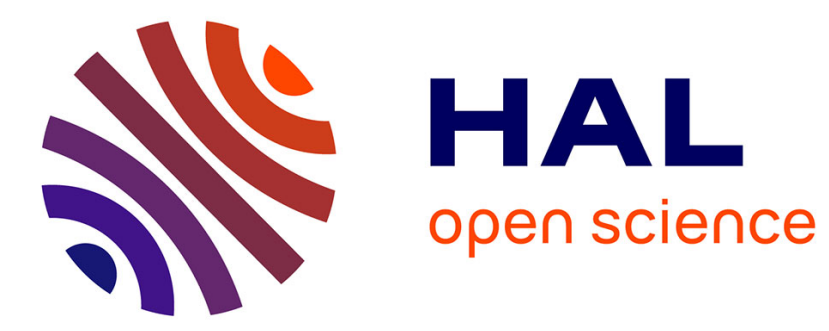

\title{
Notes on Gessner's Giraffe. Bible, Sources and Iconography
}

\author{
Thierry Buquet
}

\section{To cite this version:}

Thierry Buquet. Notes on Gessner's Giraffe. Bible, Sources and Iconography. Leu, Urs B.; Optiz, Peter. Conrad Gessner. Die Renaissance der Wissenschaften (The Renaissance of Learning), De Gruyter Oldenbourg; De Gruyter, pp.557-579, 2019, 978-3-11-049696-3. 10.1515/9783110499056-030 . hal-02139257

\section{HAL Id: hal-02139257 \\ https://hal-normandie-univ.archives-ouvertes.fr/hal-02139257}

Submitted on 7 Oct 2019

HAL is a multi-disciplinary open access archive for the deposit and dissemination of scientific research documents, whether they are published or not. The documents may come from teaching and research institutions in France or abroad, or from public or private research centers.
L'archive ouverte pluridisciplinaire HAL, est destinée au dépôt et à la diffusion de documents scientifiques de niveau recherche, publiés ou non, émanant des établissements d'enseignement et de recherche français ou étrangers, des laboratoires publics ou privés. 


\title{
Notes on Gessner's Giraffe. Bible, Sources and Iconography
}

\author{
Thierry Buquet \\ CNRS - CRAHAM - Université de Caen Normandie \\ thierry.buquet@unicaen.fr
}

This document is the Post-print version of the following reference:

Buquet, Thierry. 'Notes on Gessner's Giraffe. Bible, Sources and Iconography'. In Conrad Gessner. Die Renaissance Der Wissenschaften / The Renaissance of Learning, edited by Urs Bernhard Leu and Peter Opitz, Berlin: De Gruyter, 2019, p. 557-579. DOI: $10.1515 / 9783110499056-030$

The chapter on giraffe given by Conrad Gessner in his Historia animalium ${ }^{1}$ is an important step in the long-term history of this animal, from Antiquity to pre-modern times. ${ }^{2}$ The aim of this paper is not to give an in-depth review of Gessner's chapter on the giraffe, but it will stress three topics: the specific problem of the presence of the giraffe in the Bible; some aspects of Gessner's textual sources, with a special focus on medieval authors, and the illustrations of the giraffe in the printed editions of Gessner's Historia animalium.

\section{The history of the Giraffe before Gessner's time}

First, I will set forth some quick facts about the history of giraffes. ${ }^{3}$ Giraffes (named camelopardalis in Greek and Latin) were quite well known in Antiquity, and the animal was shown rather frequently in Rome. ${ }^{4}$ After the fall of the Roman Empire, the giraffe will be kept unknown for centuries in Western Europe, as very few specimens were brought in medieval menageries, 6 or 7 maximum in Spain and Italy, in the $13^{\text {th }}$ and the $15^{\text {th }}$ Century, according to known attested sources. ${ }^{5}$ Generally speaking, written sources about this animal are quite rare in the Middle Ages. The best descriptions are given by Antique Greek texts, but these sources will be unknown in Western Europe until the first half of the $15^{\text {th }}$ Century. Medieval Latin authors could rely only on the very bad description given by Pliny, who does not mention his height and the length of his neck! 6

The arrival of the animal in Italy in the $13^{\text {th }}$ Century will create the name "giraffa", built on the Arabic zarāfa, "giraffe". In this century, Thomas of Cantimpré, Vincent of Beauvais and Albertus Magnus give some pretty good descriptions of the giant beast. But they were not able to identify this new animal, the zaräfa-giraffa, with the camelopardalis, because of the absence of the long neck in Pliny's Historia naturalis. Medieval compilations and transformations of the Arabic zoonym will [558] bequeath in the transmission of natural history different names for one animal: camelopardalis (the Antique name), anabulla (corruption of nabun in Pliny's description), oraflus or orasius (transformation

\footnotetext{
${ }^{1}$ Gessner (1551), p. 160-162.

2 For a general survey of the history of the giraffe in the Middle Ages, see Buquet (2012).

3 I am currently writing a book on this topic, from Antiquity to Modern times.

${ }^{4}$ Gatier (1996); Gatier (2005).

${ }^{5}$ Buquet (2012).

${ }^{6}$ Pliny (1940), p. 52 (Historia naturalis VIII, 27, 69).
} 
of the Arabic zarāfa) and seraffa (Albertus Magnus) and finally giraffa from the end of the $13^{\text {th }}$ Century. ${ }^{7}$

The identification of the contemporary true giraffe to the antique camelopardalis is explained towards the end of the $15^{\text {th }}$ Century. Before this time, only one medieval scholar, Pierre Bersuire, in the $14^{\text {th }}$ Century, had given the synonymy between the two zoonyms (Camelopardalis... Et istud animal vulgariter dicitur ieraffa), but without justifying it. ${ }^{8}$ In 1487, Lorenzo de' Medici received a giraffe from Egypt, and other specimens were shown in Italy at this time. So, humanists like Angelo Poliziano, Antonio Constantius and other could compare what they sauw to what they had read in Greek texts, edited and translated in Italy in the $15^{\text {th }}$ Century, as Diodorus, Heliodorus, Oppian, Strabo and others, authors who give very good descriptions of the giraffe. So, at the end of the $15^{\text {th }}$ Century, the giraffe and the camelopardalis are brought together as a unique zoological reality, through direct observation and philology. ${ }^{9}$ So, when Gessner writes his Historia animalium, even if he probably had never saw a living giraffe, he could build his own description of the camelopardalis on recent and reliable written sources.

\section{The Giraffe in the Bible: A philological and zoological puzzle}

The first topic of this article deals with the special interest of Gessner regarding the presence of the Giraffe in the Bible, in the Deuteronomy book, 14.5. In the Greek translation of the Bible, the Septuagint, the word kamelopardalis is used to translate an unknown animal, the zemer, which is considered, among other quadrupeds, as a clean and edible ruminant. ${ }^{10}$ Here is the passage, from the Latin Bible (the text is from the Commentarium bibliorum by Konrad Pellikan) ${ }^{11}$ :

14.4 Hoc est animal quod comedere debetis, bovem et ovem et capram, 14.5 cervum et capream, bubalum, tragelaphum, pygargum, orygem, camelopardalum. 14.6 Omne animal quod in duas partes findit ungulam et ruminat, comedetis.

These are the animals you may eat: the ox, the sheep, the goat, the deer, the gazelle, the roebuck, the wild goat, the ibex, the antelope, and the mountain sheep. [559] Every animal that parts the hoof and has the hoof cloven in two and chews the cud, among the animals, you may eat. ${ }^{12}$

This zemer is nowadays considered to be a kind of mountain goat, in the following of the protestant French scholar Samuel Bochart, who was the first in the $17^{\text {th }}$ Century to demonstrate this identification, in his treatise on Bible animals, the Hierozoicon, published in $1663 .{ }^{13}$ His method was mainly philological, comparing Hebrew and Arabic roots to eastern zoological medieval knowledge. ${ }^{14}$

There were many debates among humanists and theologians in the $16^{\text {th }}$ Century about this identification of the zemer ${ }^{15}$. They have to choose between the fidelity to the Hebrew Bible and the authority of the Latin translation. In this context, Gessner was puzzled by the identification of the Hebrew zoonym zemer to the camelopardalis. At the beginning of

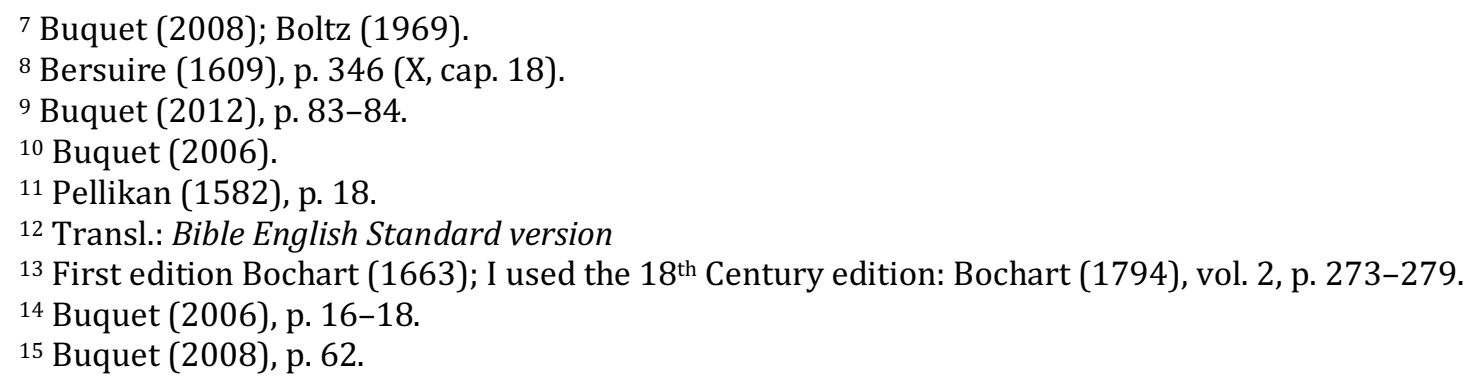


his description of the giraffe, Gessner makes his own philological enquiry on this translation problem, quoting Hebrew medieval scholars, namely Rabi Jonah and David Kimhi. ${ }^{16}$ Gessner says that Jewish authors have sometimes translated zemer into "giraffe", but others into alces (elk) or rupicapra (chamois). He finally concludes that the zemer was probably a giraffe, thus contradicting Luther's German translation of the Old Testament, which renders the zemer into an "elend" (the elk, Alces alces). ${ }^{17}$

In his chapter on the elk (De alce), Gessner rejects some other Hebrew traditions that said, according to some Jewish Scholars, that the zemer is an elk or a mountain goat (proinde non assentior Judæis illis, qui Deuteronomii cap 14 zamer alcen interpretantur: quamquam alii pro eadem rupicapram...). ${ }^{18}$ Gessner says that he prefers to acknowledge to the "giraffe" interpretation (alii camelopardalin reddunt; mihi ad postremam animus magis inclinat). ${ }^{19}$ The arguments presented by Gessner are mainly geographic when refusing the hypothesis of the alces, as he mentions that elks and chamois are foreign to the Holy Land. Luther's translation of the animal names in the Deuteronomy was guided by the purpose of edification of Northern and German people: so Luther used several animals of European origin: the elk, the chamois and the aurochs. ${ }^{20}$ [560]

Gessner writes that the giraffe comes from Ethiopia, according to Antique and medieval sources, and not from the Near East... which is quite a contradiction, comparing this to his opinion about the elk, which cannot be indentified as the zemer because of its northern origin.

Gessner is also puzzled by the fact that no one can say if the giraffe is edible or not, because this animal is very rare and exotic:

...nec obstat quod camelopardalin, nusquam in cibum venisse legerimus : rarita enim et peregrenitas facit ut cibo eam nemo experiatur. ${ }^{21}$

(...which is not contradictory to the fact that we have never read anywhere that somebody has ever eaten its flesh; as it is a rare and foreign animal, nobody ever experienced eating it).

These reflexions given by Gessner on this topic are not surprising, if we consider the importance of Bible study in the $16^{\text {th }}$ Century. Many translations are given at that time, in French, German or Italian, and they vary regarding the translation of the zemer, between giraffe, "camelopard" or chamois. ${ }^{22}$ Konrad Pellikan, in his Commentarium bibliorum quoted earlier and published between 1532 and 1539, suggested in his commentary to translate the camelopardalis of the Latin Bible into rupicolarum caprarum, a mountain goat. Surprisingly, Pellikan does not use the same animal in his new translation of the Bible, published in Zürich in 1544, but uses tarandus, one of the Latin name for the elk. ${ }^{23}$ Obviously, Pellikan uses here Luther's list, and he gives a literal translation of the German zoonyms in Latin, keeping chamois, steinbock, unicorn and elk. ${ }^{24}$ Even inside the

\footnotetext{
16 Ibid., p. 61-62.

17 Luther (1523), fol. $143 \mathrm{v}$.

18 Gessner seems to use Sebastian Munster's translation of the Hebrew Bible in Latin (listed in Gessner's sources, no 1). Munster translates zemer into alces: Munster (1546), p. 370. But Gessner does not give this source.

${ }^{19}$ Gessner (1551), p. 1.

${ }^{20}$ List of the animals translated by Luther: Ochsen (ox), Schaff (sheep), Zigen (goat), Hirs (deer), Rehe (roe deer), Gemps (chamois), Steinbock (bouquetin), Eynhorn (unicorn), Urochs (aurochs) und Elend (elk).

21 Gessner (1551), p. 160.

22 Buquet (2008), p. 62-63.

23 Pellikan (1544), fol. 81.

${ }^{24}$ Hoc est pecus quod quod comeditis, bovem, pecudem ovium, et pecudem caprarum, cervum, capream, ibicem, hircocervum, unicornem, urum et tarandum.
} 
production of a single author, one can find contradictions, reinforcing the idea that this translation was still very problematic in the $16^{\text {th }}$ Century. It is rather striking that Konrad Gessner did not use the biblical studies and Konrad Pellikan's translation made at his time and in his city, and preferring to make his own philological enquiry, and finally choosing a hypothesis never adopted by any other Protestant biblical commentator.

\section{Gessner's sources about the giraffe}

The second topic of this article is about Gessner's textual sources. On one hand, Gessner's account on the giraffe is the first complete compilation of Antique sources citing the camelopardalis; on the other hand, Gessner's use of medieval sources is rather scarce, in comparison to $15^{\text {th }}$ and $16^{\text {th }}$ Century humanists that he extensively quotes. Gessner cites 33 authors in this chapter: [561]

- 15 Antique Greek and Latin (in chronological order): Artemidorus Ephesus (the geographer), Strabo, Varro, Diodorus of Sicily, Horace, Pliny the Elder, Pausanias, Solinus, Dio Cassius, Oppian, Heliodorus of Emesa, the Augustan History (cited under the name of Julius Capitolinus), Florentinus, Geoponici graeci and saint Jerome.

- 2 medieval Jewish authors involved in biblical exegesis: Rabi Yonah (11 th C.) and David Kimhi $\left(13^{\text {th }}\right.$ C.).

- 5 medieval Latin and Greek: Thomas of Cantimpre25; Albertus Magnus, Marco Polo, "Quidam in descriptiones Terrae Sanctae"26, and Nikephoros Kallistos Xanthopoulos.

- 12 humanists (15th and $16^{\text {th }}$ C., in chronological order, by date of birth): Poggio Bracciolini (as commentator of Diodorus), Niccolò Perotti (as editor of Pliny), Raffaelo Maffei Volaterranus, Hermalao Barbaro (as editor of Pliny), Giovanni Battista Egnazio (Egnatius), Angelo Poliziano, Paolo Giovio, Julius Caesar Scaliger, Sebastian Münster, Petrus Gyllius (as editor and commentaror of Aelianus), Leo Africanus and Pierre Belon.

The medieval texts are only about $15 \%$ of the authors cited by Gessner, who gives more importance to classical and humanistic sources. One may speak of mistrust about medieval scholars; but, as a matter of fact, sources from the Middle Ages are rather scarce and give little information on the "true" giraffe. ${ }^{27}$ On the contrary, Greek and Latin sources are more detailed, and the humanists are quite eloquent about the giraffe, since the arrival of several specimens in Italy at the end of the $15^{\text {th }}$ Century, and they give good descriptions from direct observation, as Poliziano did with the giraffe given to Lorenzo de' Medici in 1487. Poliziano, in his Liber miscellaneorum, makes an important philological enquiry, comparing Greek and Latin antique sources about the camelopardalis, and identifying this Greek-Latin name to the vernacular "giraffa", its name in Italian. ${ }^{28}$ Poliziano is a very important source for Gessner, as he cites the Florentine scholar 6 times in the chapter on the giraffe, both for his use of Classical sources and for the description he made from the direct observation of the animal.

\footnotetext{
25 Thomas is quoted falsely under the name of Isidore of Seville, as we will explain later.

${ }^{26}$ See the last part of this paper about the iconography, for an identification of this author.

27 The camelopardalis and the giraffe are considered as different animals in the Middle Ages. This absence of identification is obvious for example in medieval translations from Latin to vernacular languages. Buquet (2008), p. 58-60; Buquet (2012), p. 87.

28 Poliziano (1971), p. 228-229.
} 
Another important topic to discuss is the addition of sources after the first edition of the Historia animalium. When we compare the Froschauer edition of 1551 and the Frankfurt editions of 1603 and 1620, we can observe first that all text from the first edition has been kept and second that a few additions have been made in [562] the chapter about the giraffe. ${ }^{29}$ The Frankfurt edition adds 6 authors, including 4 from the $16^{\text {th }}$ Century: Leo Africanus (Description of Africa, first published in 1550); Paolo Giovio ${ }^{30}$; Julius Caesar Scaliger (Exotericarum Exercitationum) and Pierre Belon. The edition adds 2 medieval references: Marco Polo (under the name Paulus Venetus) and the byzantine Nikephoros Kallistos. With these additions, Gessner has chosen new sources with very good descriptions of the giraffe, which bring very accurate zoological observations. For exemple, Scaliger uses the travelog of Giosafat Barbaro (1413-1494), ambassador of Venice who travelled in Persia in 1471-1472. There he saw a giraffe at the court of the king of Persia among other exotic animals. Barbaro gives a lively description, quoted at length by Scaliger, with new information about the long violet tongue of the animal, and how the giraffe uses it to catch and eat leaves from the top of the trees. ${ }^{31}$ None of the Antique, medieval and modern authors ever say a word about the giraffe's tongue, so Gessner saw the importance of this passage borrowed from Scaliger, to give a better description of the camelopardalis. Other facts brought by Leo Africanus and Paolo Giovio deals with its geographical origin and the ways of capturing the giraffe.

The addition of Scaliger, Paolo Giovio and Leo Africanus, forms a long paragraph of a dozen lines in the Frankfurt edition. ${ }^{32}$ These pieces of information are the bigger addition on the chapter about the giraffe. This new paragraph has already been published in the very beginning of the chapter on the giraffe in the second edition of the Icones animalium published in Zürich in 1560, with exactly the same and extensive sequence of text. ${ }^{33}$ As Gessner writes in the introduction of 1560 , he wanted to shed light on new information, absent from the 1551 edition of the Historia animalium. ${ }^{34}$ Unfortunately, Gessner didn't annotate the chapter on the giraffe in his personal exemplar. ${ }^{35}$ The new paragraph is inserted in the middle of the chapter in the Frankfurt edition, with an extract from Nicephorus Callisthus. As Gessner doesn't use for the giraffe a formal structure as in other chapters, ${ }^{36}$ [563] (information that is only concerned with the names of the giraffe, its geographical origin and its morphology) it is difficult to explain why he decided to place the text where he did. We can only observe that these quotations (including Nicephorus but excepting Scaliger) mention the geographic origin of the animal (African, Indian, subequatorial) and are inserted just after a quotation of Pausanias about the Indian origin of the camelopardalis. The additional paragraphs are inserted before a long paragraph telling the story of the giraffe given to Lorenzo da Medici, in correspondence to specimens

\footnotetext{
${ }^{29}$ Gessner (1620), p. 147-149.

30 Gessner does not cite namely the book, only the author. Nevertheless, we can identify the quotation about the giraffe, borrowed from his Historiarum sui tempis I, book 18 (Firenze, 1550). We can find another mention of the giraffe of Lorenzo il Magnifico in the praise of the Egyptian sultan Qatbay in the Elogia virorum bellica virtute illustrium (ed. princeps Venice, 1546). In the first edition of the Historia animalium, Gessner cites only one book by Paolo Giovio, the De piscibus, among his sources (n 218 ).

31 Barbaro and Contarini (1873), p. 54.

32 Gessner (1620), p. 148, l. 48-59.

33 Gessner (1560), p. 41-42.

34 In the first edition of the Icones (1553) there was no text with the engravings. For the second edition, Gessner chose to add "nomina \& descriptiones", most of them new and absent in the Historia animalium. See Gessner (1560), introduction, p. 7.

35 For a description of this book, see Leu, Keller, and Weidmann (2008), p. 130 (catalogue 159).

${ }^{36}$ Each chapter is structured in 8 parts, form A to H. See liminal chapter « Ordinis ratio, quem per singulas fere animalium historias secuti sumus ». See Pinon (2005), p. 248-249; Schmutz (2016), p. 130.
} 
brought in Antique Rome. The only objective explanation is that we can observe that all the additional texts are inserted just before or after a paragraph mark ( $\mathbb{T}$ ) of the first edition.

The very short reference to Belon about the giraffe's horns is quoted from Les Observations de plusieurs singularitez et choses mémorables published in $1553 .{ }^{37}$ It is quite surprising that Gessner doesn't use for the second editions of the Icones animalium and the Historia animalium the rather detailed description of the animal by Belon, who saw living specimens in Cairo. As a matter of fact, Belon's description gives new information, and not only the quite accurate description of the horns: Belon explains that the animal is able to sit down, and needs to spread wide open its forelegs to graze on the ground. ${ }^{38}$

\section{Medieval sources}

Albertus Magnus seems for Gessner his major medieval reference for animals, despite the fact that he is complaining about the "numerous errors" found in his zoological work, 39 and Gessner cites Agostino Nifo who said that Albertus' writings counted as many errors as words (in numeris erroribus, inquinati, ita ut Niphus totidem fere errores in esse scribat quod verba). ${ }^{40}$ For the giraffe, Gessner cites Albertus 6 times, about the different names of the animal (anabula, camelopardalis and oraflus), the descriptions of the camelopardalis and the oraflus. ${ }^{41}$ All 6 quotations come from Albertus' De animalibus. This zoological treatise is a commented paraphrase of Aristoteles' treaties on animals, with additional books, where species are classified by alphabetical order, mainly borrowed from Thomas of Cantimpré. Gessner seems to use mainly these last books and doesn't cite other passages of the paraphrase of Aristotle by Albert, where the last gives, in two passages, some little information not present in the final books: that the giraffe has a huge body, [564] which allows it to defend against predators, and that the anterior part of the body is highly elevated. ${ }^{42}$ Albertus' zoological treatise has been edited since the last quarter of the $15^{\text {th }}$ Century, and thus was easily available, but it doesn't seem that Gessner did possess in his own library one exemplar of this book. ${ }^{43}$

Another major source for medieval encyclopaedism on animals is the Speculum naturale by Vincent of Beauvais and Gessner mentions it in the list of authors used in the Historia animalium. ${ }^{44}$ He sometimes quotes without ambiguity Vincent of Beauvais in the Historia animalium, but not about the giraffe. On the contrary, Gessner quotes Isidore of Seville about the orasius instead of the true medieval source, which we can identify at first glance as coming from Thomas of Cantimpré. Thomas of Cantimpré was unknown by name in the $16^{\text {th }}$ Century. But some humanists know his encyclopaedia, the Liber de natura rerum, ${ }^{45}$ dating from circa 1240 . The humanist Petrus Candidus Decembrio reedited the zoological part of this book under the title De animantium naturis, written

\footnotetext{
37 Belon (1553).

38 Belon (2004), p. $72-73$ (chapt. 49).

39 On the influence of Albertus on Renaissance natural history, see Glardon (2011), p. 33-39.

${ }^{40}$ Gessner (1551), no. 122. Cited by Glardon (2011), p. 34. Nifo (Niphus) is cited under the number 157 of the list of authors cited in the Historia animalium.

${ }^{41}$ Albert le Grand (1916), p. 1357 (anabulla), 1368 (camelopardalis), 1417 (oraflus).

42 Albertus Magnus (1916), p. 889, 963.

43 Gessner had a minor treatise of Albert, the De Secretis mulierum, but no other work. See Leu et al. (2008), p. 260.

44 Gessner (1551), no. 139.

45 See edition: Thomas de Cantimpré (1973). Mattia Cipriani is planning a new critical edition from his $\mathrm{PhD}$ (2014).
} 
around 1458-1460, and kept in a unique manuscript. ${ }^{46}$ Petrus Candidus says that the author of the original text was unknown to him. Gessner has probably never heard about Petrus Candidus, as he doesn't cites him in the list of sources of the Historia animalium, and because Gessner's passage on the orasius matches perfectly to the original Thomas text, and not to the rewriting by Petrus Candidus, who reviewed the Latin original medieval text. It's difficult to say if Gessner had been in contact with one of Thomas' manuscripts, and the Liber de natura rerum remained unpublished until the $20^{\text {th }}$ Century. On the one hand, many manuscripts of the Liber de natura rerum were in circulation in central Europe at the end of the Middle Ages; on the other hand it was the third version of the text (Thomas III) which has the greater diffusion in Austria and southern Germany, ${ }^{47}$ and this third version has no entry for oraflus or orasius, neither for camelopardalis, ${ }^{48}$ and Gessner's text refer explicitly to this zoonym in the quotation of Isidore/Thomas.

To evaluate the use of the use of medieval encyclopaedists in the Historia animalium, we can also consider the way Gessner cites Thomas as part of his medieval sources in the preface of his De quadrupedibus: [565]

Liber de natura rerum authoris innominati, passim apud recentiores illos, quorum impurus sermo latinus est, citatur, Vincentium, Albertum, ex quibus nos omnia quae non prorsus absurda erant mutuati sumus. ${ }^{49}$

Liber de natura rerum, from an unnamed author, quoted in various passages by the more recent Vincent and Albert, in a corrupted Latin language, from which we borrowed all that what was not totally absurd.

The end of the sentence confirms that Gessner doesn't often quote directly Thomas of Cantimpré, but mainly through Albertus Magnus or Vincent of Beauvais. ${ }^{50}$

When Gessner cites some obscure authors (alli quidam obscure authores) ${ }^{51}$ about the anabulla, does he include Thomas of Cantimpré? An important clue is that Gessner could have only cited the title, Liber rerum or Liber de natura rerum. But he does not cite the information about the giraffe. Thus, the best hypothesis is that Gessner quotes for this extract Vincent of Beauvais' Speculum naturale. Gessner cites first "Isidorus" about the "nabun", a name given to Pliny to the giraffe, and second about the orasius. Vincent's account on the orasius is directly borrowed from Thomas of Cantimprés oraflus and matches perfectly to Gessner's quote; the mention of "nabun" is taken from the chapter on camelopardalis by Vincent, and the last quotes Isidorus as his main source for this animal (in the rubric of the chapter) and Pliny inside the text. ${ }^{52}$ Gessner cites the source of Vincent (Isidorus) for the "nabun", and makes a mistake in quoting Isidorus for the orasius, where Vincent quoted the Liber de natura rerum (Thomas) when writing about this animal. ${ }^{53}$

${ }^{46}$ De animantium naturis (15-16 th Century) Biblioteca apostolica Vaticana, urb. lat 276; Pyle (1984); Pyle (1996).

47 Van Den Abeele (2008), p. 151-152.

48 Thomas de Cantimpré (1992). We refer to a work-in-progress edition of the text, based on 5 manuscripts, still unpublished. The new edition project, based on 23 manuscripts, is forthcoming at Wiesbaden, Reichert Verlag, WILMA series (see http://fordoc.ku-eichstaett.de/1701/).

${ }^{49}$ Gessner (1551), no. 139 and 140.

${ }^{50}$ For other references to Thomas in the ornithological book of Gessner, see the contribution of B. Van den Abeele in the current proceedings. Van den Abeele also mentions that references to Thomas by Gessner mainly come from Vincent of Beauvais.

51 Gesner (1551), p. 162, l. 31.

52 Edition used: Vincent de Beauvais (1476), without pagination.

53 Vincent de Beauvais (1624), cols 1385 (anabulla), 1387-1388 (camelopardus) 1435 (orasius). 
We can consider that Gessner cites Vincent's encyclopaedia instead of Thomas, because he uses the zoonym orasius, where Thomas uses oraflus. The change of " $\mathrm{fl}$ " to "si" in the middle of the world is specific to the editions of Vincent of Beauvais' Speculum naturalis. There is also minor difference between Thomas's text and Vincent's quotation: in the first sentence of the chapter, Thomas says that the oraflus is an extraordinary animal, about which Nature had given such beauty in its colours that it makes him superior to every animal. This first sentence has not been kept by Vincent, and nor in Gessner's chapter. All Gessner's text matches perfectly to Vincent, even in the order of words (that Vincent slightly modified from Thomas's text), apart from a sentence not kept by Gessner, saying that the oraflus seems to be conscious of his own beauty, and when he sees men standing around him, he turns around on all sides, drawing everyone's eyes to admire him. Gessner doesn't keep this passage from Vincent, prefering to quote Albertus, who cited Thomas for the same passage, [566] rewriting it in a shorter form. Gessner also mentions that Albertus gives better information about the colours of the giraffe, saying that among the various colours of the hide, red and white are the most frequent. So Gessner selects the quotations among his sources, thus avoiding repetition.

It is striking that Gessner does not cite Bartolomeus Anglicus, another famous medieval encyclopaedist from the $13^{\text {th }}$ Century, which had a great diffusion not only in medieval manuscripts but also in printed editions (more than forty until the beginning of the $\left.17^{\text {th }} \mathrm{C}.\right)^{54}$, in Latin and in various vernacular translations. ${ }^{55}$ Although Bartholomeus is cited among the authors used in the Historia animalium, ${ }^{56}$ Gessner doesn't cite this source for his description of the giraffe. It is not so surprising if we consider that Bartholomeus has only compiled Pliny, Isidore and the Glossia ordinaria of the Latin Bible about the camelopardalis. ${ }^{57}$ Bartholomeus doesn't mention the other names of the giraffe, anabulla nor oraflus. On the contrary, Thomas, Vincent and Albertus bring new information and better descriptions of the animal that was seen at their time in Europe. Thus, they add upto-date knowledge on the giraffe, alternative and complementary to Classical sources. On the opposite side, Bartholomeus didn't bring any novelty, so Gessner maybe prefers not to add some superfluous and repetitive information.

Gessner also sourced accounts from medieval pilgrims and travellers including Marco Polo and an anonymous pilgrimage travelogue (Quidam in Terrae sanctae). I will discuss the latter when I consider the illustrations. Marco Polo is only cited in the Frankfort edition from the beginning of the $16^{\text {th }}$ Century; the addition is rather short, simply mentioning that giraffe are found in "Abasia" (Abyssinia). One important point to emphasize is that Gessner does not use medieval travel accounts, except Marco Polo and the anonymous pilgrim. I have found in more than 30 medieval pilgrim travelogues quite accurate descriptions of the giraffe and other exotic animals seen in the Holy Land, in Egyptian landscapes or at the Sultan's menagerie in Cairo. ${ }^{58}$ Gessner might have found good anatomical details in these texts; but most of these travelogues remain unpublished in the $16^{\text {th }}$ Century, and we know that Renaissance scholars were quite wary and suspicious about medieval imagination and their taste for monsters and mirabilia. They preferred to rely on modern testimonies published or send by Humanists whom they could trust.

\footnotetext{
54 Meyer (2000), p. 388-407.

55 Ducos (2014).

56 Gessner (1551), no. 125.

57 Bartholomeus Anglicus (1483), Book XVIII, chapt. 18.

58 Buquet (2013).
} 
Apart from Marco Polo, we find a new author, Nicephorus Callisthus Xanthopoulos, a $14^{\text {th }}$ Century Byzantine priest who wrote a Historia ecclesiastica. Gessner quotes a passage about the giraffe from this work, where Nicephorus mentions the origin of the giraffe ( $s u b$ aequinoctiali ad orientem et meridiem) and gives an [567] external description. The Historia ecclesiastica was translated into Latin by Johannes Langus and was edited in Basel in 1553, ${ }^{59}$ just after the first edition of Gessner's Historia animalium. Just before, the first Latin translation was edited in an anthology in Basel in 1535. This text was, however, probably unknown to Gessner as he does not mention Nicephorus in the first edition of the Historia animalium. Nicephorus' Historia ecclesiastica had a great editorial success during the $15^{\text {th }}$ and the $16^{\text {th }}$ Century. It was published in dozens of editions. ${ }^{60}$

The last and bigger addition on the giraffe in the second edition of the Historia animalium is found at the end of the chapter. It is dedicated to images of the giraffe that I will now discuss in more detail.

\section{Illustrating the giraffe in four editions}

In the first editions of the Historia animalium (1551) and of the Icones animalium (1553), there is only one engraving to illustrate the giraffe, the same one for each book. The picture shows a quadruped with a spotted hide, short hind legs, and two big curved horns (fig. 1).

Gessner uses two images to illustrate the giraffe in the second editions of the Icones animalium, and we can find the same two pictures in the second edition of the Historia animalium from the $16^{\text {th }}$ century. Gessner adds a new picture (fig. 2) in the additions of the second edition of his Icones animalium, explaining that it is a better image than the one shown in the first edition and reprinted in the main part of the book (Icon accuratior quam exhibita supra pag. 41). ${ }^{61}$ Urs B. Leu studied the story of the second image and its origin. The picture was inspired by a woodcut from a drawing by Melchior Lorichs (Lorck). Lorichs travelled to Constantinople between 1555 and 1559 as an art adviser of the Flemish diplomat Ogier Ghislain de Busbecq, and he made there many pictures (people, views of the city, various curiosities). He drew also an image of a giraffe send as present to the Ottoman sultan, Suleiman the Magnificent. Later, this picture will be printed by Hans Adam in Nuremberg (fig. 3). ${ }^{62}$ This is confirmed by Gessner himself in the Icones animalium, as he writes that the picture was printed in Nuremberg from a drawing by Melchior Luorig, from a living model given to the great Turk emperor in Constantinople; the picture was send by some friend in Germany:

\footnotetext{
...diligenter et probes depictum per Melchiorem Luorig Constantinopoli (ubi Turcarum imperatori hoc animal donatum fuit) et amico cuidam in Germaniam transmissum, anno Salutiferi partes M.D.LIX. $)^{63}$
}

\footnotetext{
${ }^{59}$ Nicephorus Callistus Xanthopulos (1553).

60 Mornando (2007), p. 265-267.

${ }^{61}$ Gessner (1560), p. 124-125.

${ }^{62}$ Leu (1993); Fischer (1974).

${ }^{63}$ Gessner (1560), p. 124-125.
} 


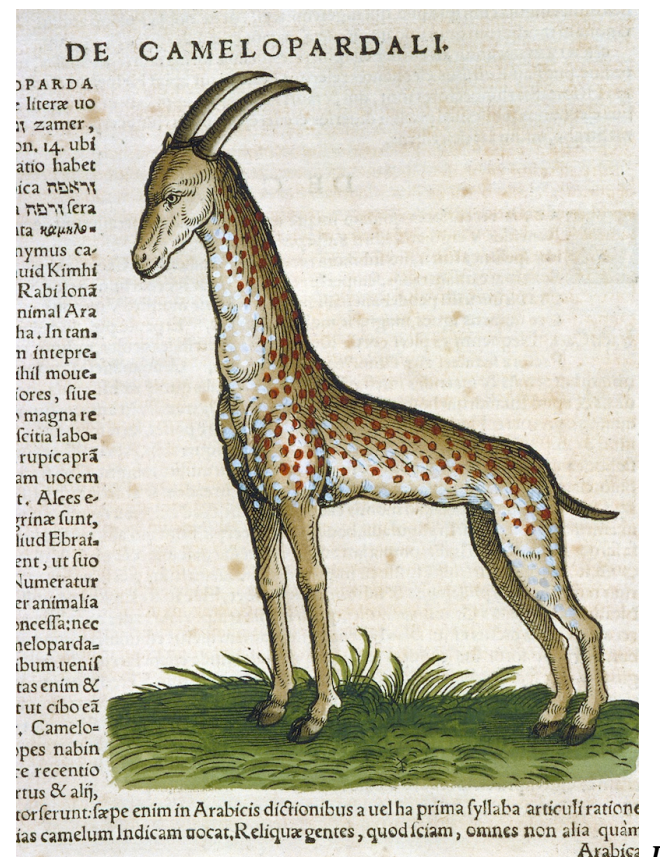

Arabicic Figure 1.

\section{[569]}

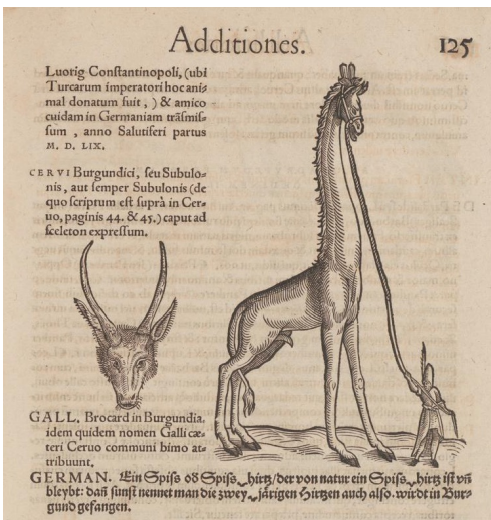

Figure 2

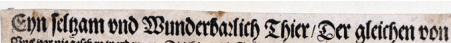

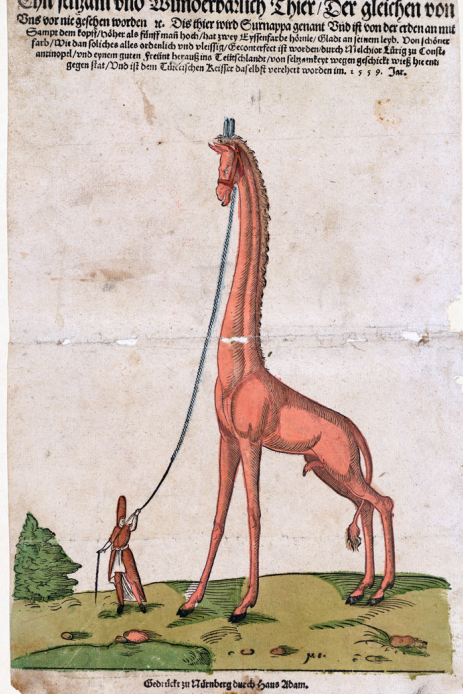

Figure 3

The image was printed in 1559, short before the second edition of the Icones animalium (1560): this could explain why this picture has been rejected at the end of the 
volume, being part of the Additiones, and not replacing the "Breydenbach" picture in the main part of the book. The first image (p. 42, fig. 4), comes with a caption:

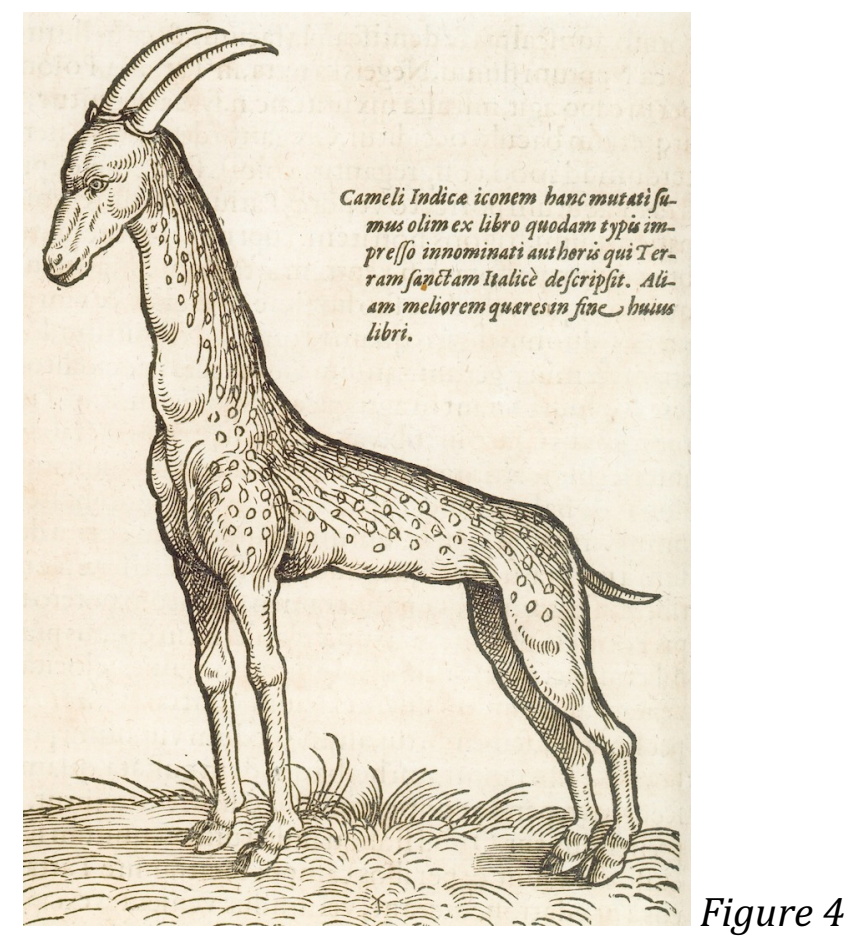

Cameli Indicae iconem hanc mutuati sumus olim ex libro quodam typis impresso inominati authoris qui Terram sanctam Italice descripsit. Aliam meliorem quaeres in fine huius libri.

This image of the "Indian camel" was borrowed some time ago from the book of an unnamed Italian author, who described the Holy Land. You will find another better one at the end of this book.

[571] The "better image" is without any doubt more accurate, although it doesn't represent the pattern of the hide's colours: the horns are more naturalistic than in the Reuwich picture, as is the tail longer, and more realistic. We'll try to understand why this image was used despite the fact that Gessner was conscious of its poor quality. The engraving was inspired by a woodcut by the Dutch artist Erhard Reuwich (fig. 5), illustrating the edition of the travels of Bernard Breydenbach (ed. princeps Mainz 1486). As a matter of fact, some engravings of the Historia animalium were copied from the iconic woodcut of Breydenbach's Travels edition, gathering various animals seen in Egypt and the Holy land by the pilgrim: giraffe, wild man, salamander, camel and Indian goats. ${ }^{64}$ However, what at first glance appears obvious is much more complex as we shall see.

In the caption of the Icones (fig. 4), Gessner mentions an anonymous Italian travel as being the source of this image, which doesn't fit with the Breydenbach travels. Among various Italian pilgrimages of the end of the Middle Ages and the $16^{\text {th }}$ Century, I can identify this anonymous travel through the Holy land, Syria and Egypt as the Viaggio da Venezia al san Sepulchro. ${ }^{65}$ The Viaggio has been printed many times during the $16^{\text {th }}$ century (14 before 1550) in many different versions for a total of about 60 editions until the $18^{\text {th }}$ Century. In the $17^{\text {th }}$ century, it was published under the name of Noe Bianchi (or Bianco), a false authorship, borrowed from another successful pilgrimage guide from the

${ }^{64}$ Kusukawa (2010), p. 308, 324, 326-327.

${ }^{65}$ Contra Kusukawa (2010), p. 309 note 36, who assumes that the image of the 'camel-giraffe' of the Icones animalium comes from an Italian version of Breydenbach's travels. 
$16^{\text {th }}$ century. Jean-Luc Nardone and Kathlyn Moore have shown how complex is the history of these editions, and that the main source for the Viaggio is a travel account about the Holy Land written by Niccolo da Poggibonsi in the $14^{\text {th }}$ century. ${ }^{66}$ Although the text of the Viaggio da Venezia varies in many passages in the different editions, the chapter describing animals in Egypt is always kept in the same form, with absolutely no changes in the text. There are also no major changes in the illustrations of the giraffe in the Viaggio. As you can see in the fig. 6, the picture of the giraffe is different from Reuwich's image. ${ }^{67}$ An explanation for this difference can be found in Gessner's text, both in the first and second editions of the Historia animalium:

Quidam in descriptiones Terrae Sanctae, ex qua etiam hanc imaginem mutuati sumus, girapham caprae comparat, et pellem eius in ventre piscatorio reti, ob virgulas nimirum cancellatim digestas. [quod in pictura nostra expressum non est].

Somebody, in the descriptions of the Holy Land, from which we borrowed this picture, had compared the giraffe to a goat, its hide on the belly to a fishing net, certainly because of the little branches divided in lattice [which is not represented in our picture].

\section{[572]}

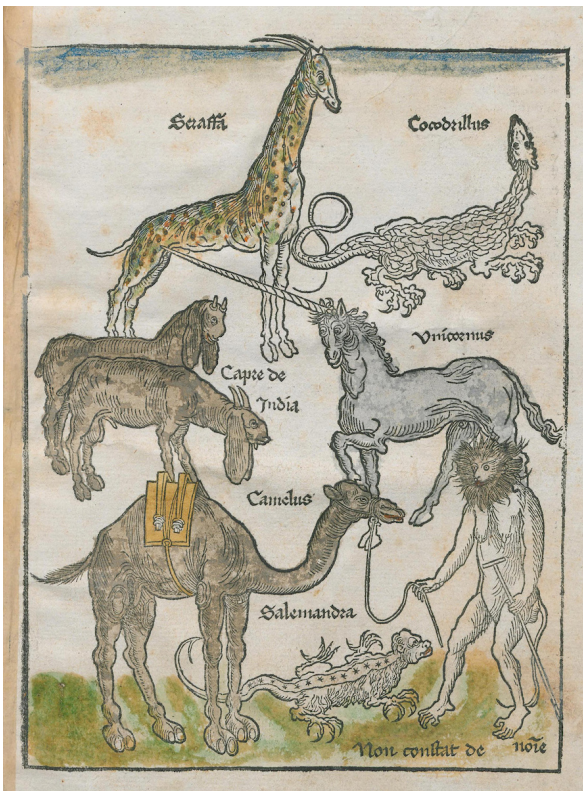

Figure 5

[573]

${ }^{66}$ Moore (2013); Nardone (2015); Nardone (2007), p. 13-14.

${ }^{67}$ Nardone (2006). 


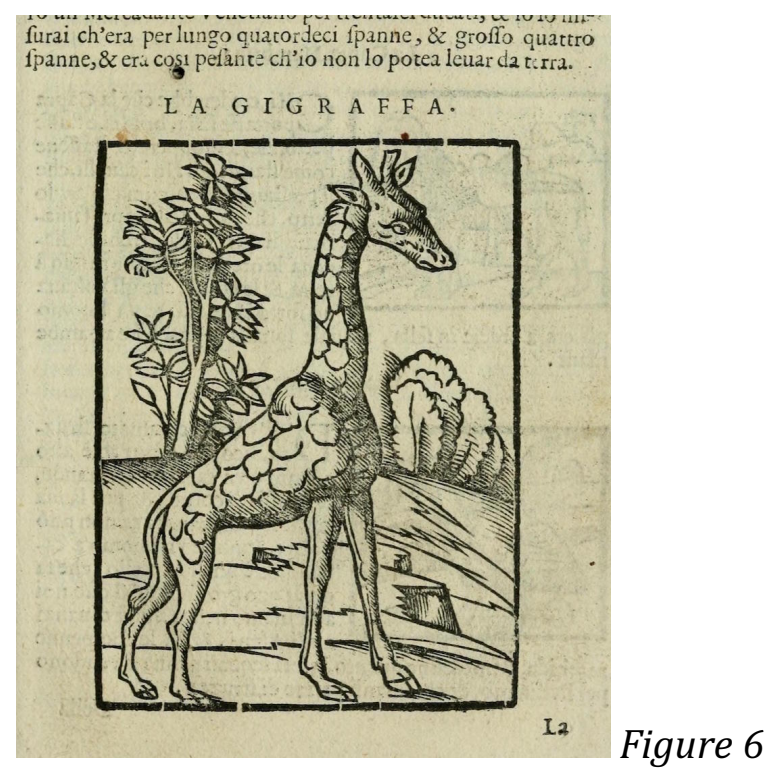

"Quidam in descriptions Terrae Sanctae" is Gessner's textual source, the anonymous Viaggio, inspired by Niccola da Poggibonsi's travels. The passage ex qua etiam hanc imaginem... is quite puzzling: the image of the Historia animalium does not, however, resemble the images from the Viaggio da Venezia edition. Gessner says that the giraffe is similar to a goat while the fur of its belly looks like a fishing net. These two elements allow [574] to identify Gessner's source. First, among the 50 medieval sources on giraffes that I have studied, Poggibonsi's is the only one to compare the giraffe to a goat; second, Poggibonsi is also the only one to compare the pattern of a giraffe's hide to a fishing net. This similarity cannot be a coincidence. Here is the beginning of Poggibonsi's description of the giraffe: ${ }^{6}$

La giraffa si è fatta quasi come la capra, e il corpo suo è colorato di sotto come le rette...

The giraffe is almost made as a goat, and the body is coloured underneath like a net...

Thus, Gessner's source is identified as Poggibonsi's text and we shall assume that Gessner probably used the printed version of this text, published under the title of Viaggio da Venezia. One passage by Gessner (ob virgulas nimirum...) is not found in Poggibonsi's text, nor can it be found in the printed editions of the Viaggio. In fact, Gessner seems to be describing the picture in a $16^{\text {th }}$ Century edition of the Viaggio. As you can see in the fig. $\mathbf{6}$, the semi-circular lines on the belly symbolize the net patterning of the skin. Virgulatum means "striped", but virgula means also "line" or "twig" or "little branch". In modern French, "virgule" means "comma", the punctuation mark, and this meaning is attested in French in the $16^{\text {th }}$ century. The semi-circular rounded lines on the belly of the picture here may be compared to "commas". This description of the "virgulas" is the major clue to explain that Gessner wanted to print the Viaggio picture, as no stripped nor net pattern can be seen in the design of the giraffe's hide on the Reuwich-Breydenbach image.

The end of the sentence, between brackets (quod in pictura nostra...), is an addition from the edition of Frankfort, dating from the beginning of the $17^{\text {th }}$ century. Here, somebody (probably the editor of the text after Gessner's death) was obliged to mention that this "virgulas", commas or twigs alike, could not be seen on both pictures printed in the Historia animalium.

${ }^{68}$ Poggibonsi (1945), p. 108; Nardone (2006), para. 3. 
It appears that a mistake occurred during the printing of the first edition of the Historia animalium. Gessner probably saw with his own eyes the woodcut from the Viaggio da Venezia. In all likelihood he had planned to print this image. For an unknown reason, however, the engraving that was eventually printed was inspired by the zoological woodcut found in Breydenbachs' Peregrinationes in terram sanctam. Edward Reuwich, who travelled with Bernhard Breydenbach, designed this woodcut. The Reuwich's picture (fig. $4 \& 5$ ) shows a giraffe with long, rounded and curved horns like a cow or a goat, which is not the case for the Viaggo's picture.

Breydenbach's travelogue had become very famous since its first edition was published in 1486. The image of the giraffe, inspired by Reuwich's woodcut, was to have great success in the $16^{\text {th }}$ Century, used as a model for illustrating the editions of Arnold Van Harff (Pilgelfahrt, 1500), ${ }^{69}$ Michael Herr (Das neue Tierbuch, 1546), ${ }^{70}$ [575] and Barthelemy Aneau (Décades, 1549). ${ }^{71}$ Despite the very poor quality of this picture, in comparison to many others dating from the $16^{\text {th }}$ Century, this image was to become quite iconic in the Renaissance. The other point, already mentioned earlier, is that Gessner uses for several different animals the Reuwich's woodcut: it seems obvious that it was easier to reuse this model than searching for another one.

This explanation is reinforced by the fact that some editions of the Viaggio, published after 1518, which were originally illustrated with original pictures since the editio princeps (Bologna 1500), used sometimes some woodcuts copied from Breydenbach's Peregrinatio. ${ }^{72}$ In the Viaggio, three woodcuts come within a general presentation of the city of Damietta. ${ }^{73}$ The first with a caption Questo è il gambello il quale porta le some degli Mori (this is the camel which carry the burden of the Arabs) shows a savage man holding the leash of a camel, matching perfectly to the model of the Breydenbach engraving. The second presents four animals, "babuino", "cocodrilo", "unicornus" and "salamandra", gathered in one engraving (fig. 7), also inspired by the same woodcut; for example the edition of Venezia 1519 (Paris BnF exemplar) doesn't have the woodcut of the camel, but contains the four-animals engraving. ${ }^{74}$ The third is a picture of two goats, one with long ears, the other with a large tail, these two alike the "capre de India" of the Breydenbach woodcut. As all the animals are identified by their captions in the Breydenbach illustration, the same method is used in the second of the three woodcuts of the Viaggio. ${ }^{75}$ Lamberto Donati have already observed that, in this iconographic program based on the Breydenbach woodcut, the editor of the Viaggio chose to copy all the animals except the giraffe. Donati submitted the hypothesis that probably the Venetian publisher was not satisfied with the poor quality of the giraffe woodcut, as he may have seen better paintings of this animal in Italy, especially those of Bellini in Venice. ${ }^{76}$

It is also surprising that Gessner didn't chose to reuse the nice picture of the giraffe in Belon's book that have been made from nature ("Et l'ayant fait retirer au naturel, en avons bien voulu ici suivant mettre le portrait"). ${ }^{77}$ Pictures given by Belon and Thevet are better than those chose by Gessner, both Reuwich's and Luorich's. It's thus puzzling to

\footnotetext{
${ }^{69}$ Arnold von Harff (1946), p. 120.

${ }^{70}$ Herr (1994), p. 225-226.

${ }^{71}$ Aneau (1549), chap. p. IV, 9. This edition also borrows to Breydenbach the picture of the salamander (stellion).

72 Moore (2013), p. 361.

73 Viaggio da Venetia (1606), f. sign. L7-L8.

74 Viaggio da Venetia al sancto sepolchro et al monte Synai (1519), Paris, BnF A-6709 (3).

75 Nardone (2006), § 4.

76 Donati (1938), p. 265-266.

77 Belon (2004), p. 73.
} 
understand why Gessner didn't choose the illustrations of the French naturalists, ${ }^{78}$ or any other of that time. ${ }^{79}$ Gessner seems to have not heard [576]

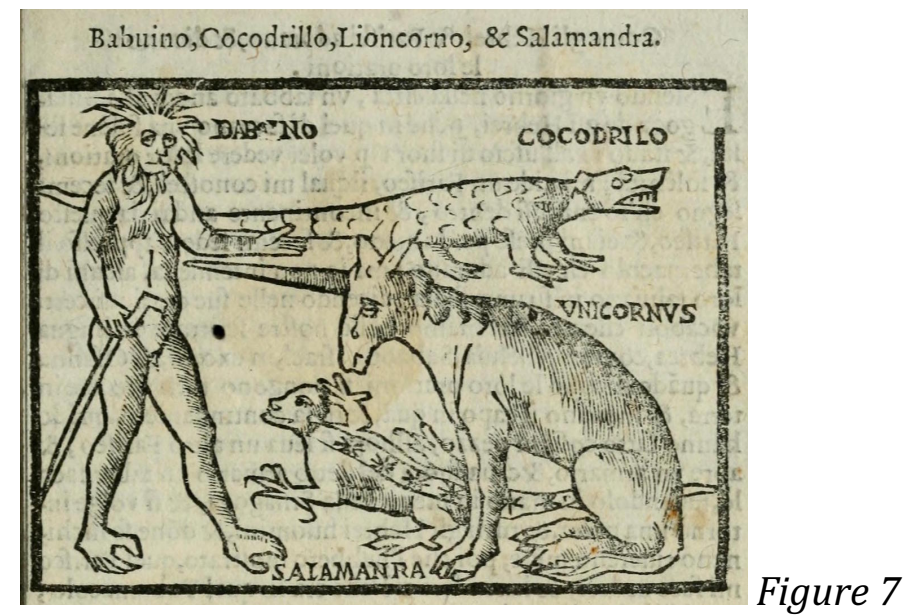

of the various sketches and paintings involving giraffes drawn from nature that were produced in Italy at the end of the $15^{\text {th }}$ Century: he may have found among them very beautiful portraits of true giraffes, ${ }^{80}$ but very few of these pictures have been printed. One is found in a manuscript of the Historia senense by Sigismondo Tizio, dating from the beginning of the $16^{\text {th }}$ Century. ${ }^{81}$ Lorenzo da Medici's giraffe had also inspired another woodcut, designed by Niklaus Stoer, and printed in Nuremberg in 1529 by Wolfgang Resch. ${ }^{82}$ [577]

\section{An iconographic epilogue by Teodoro Ghisi}

The "Breydenbach" model has been used at the end of the $16^{\text {th }}$ Century by the Italian painter Teodoro Ghisi (d. 1601) in his illustration in the manuscript of Petrus Candidus in the chapter dedicated to the "camelopardalis" (f. 14v). In this manuscript (Biblioteca apostolica Vaticana, Urb. Lat 276), written in 1460, but illustrated at the end of the $16^{\text {th }}$ Century, ${ }^{83}$ Ghisi copies many engravings from Gessner's books, mainly the edition of the Icones animalium from 1560 and the fifth volume of the Historia animalium, published by Froschauer in 1587.84

As you can see in the fig. 8, one anonymous hand (a reader? the owner of the manuscript?) wrote near the picture (f. 14v), the word "capra" or goat. Here, you can see the same equivalence being made between giraffe and goat in the Viaggio, here probably because of the long rounded and sharp horns created by Edward Reuwich.

${ }^{78}$ The question of better quality of Belon's and Thevet's pictures had already been posed by Leu (1993), p. 72-73.

${ }^{79}$ For a study on the first pictures of giraffe at the Renaissance, see Fischer (1974).

80 Buquet (2012), p. 84-87; Dittrich, Dittrich, and Faust (1993), p. 4-8; Cuttler (1991); Joost-Gaugier (1987); Donati (1938).

81 Donati (1938).

82 Cuttler (1991), p. 170; Donati (1938), p. 258-259.

${ }^{83}$ Pyle (1996), p. 268.

${ }^{84}$ Ibid., p. 304. 


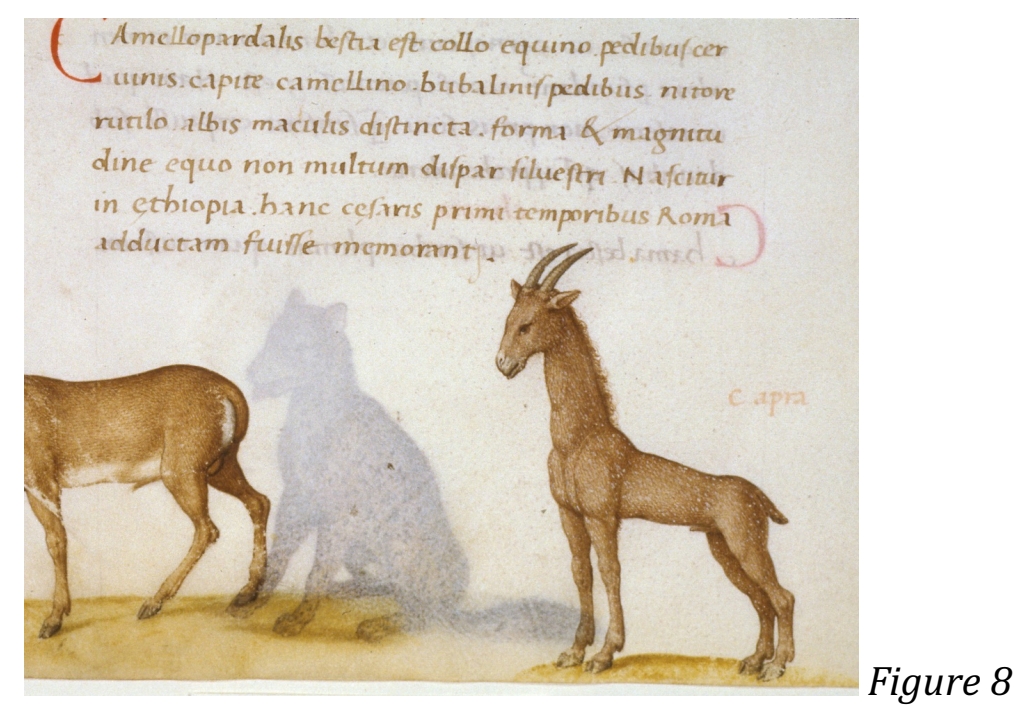

\section{[578]}

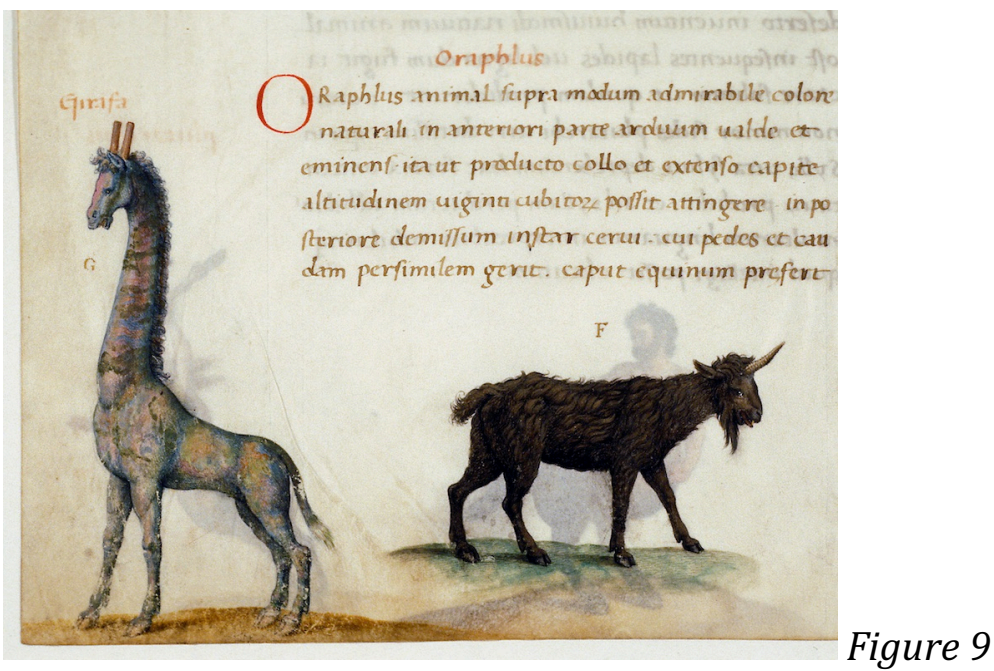

In another chapter describing the giraffe by the name of oraflus (f. 46v, fig. 9), Ghisi uses another iconographic model, which looks like a true giraffe - probably the one by Melchior Luorig. Despite the odd name given to the animal, the anonymous hand wrote "girafa" near the image since the writer obviously recognized the animal by name as well. This confusion between giraffe and goat in Ghisi's picture of the camelopardalis could thus explain why the editor of the Historia animalium preferred to use the BreydenbachReuwich image rather than the Viaggio woodcut simply because Reuwich's image looks like a goat, with its long sharp horns, rather than a giraffe.

\section{Concluding remarks}

As already mentioned in the introduction of this article, Gessner's chapter on the giraffe is a very important step in the history of this exotic and rare animal. Gessner gathered here a rather exhaustive compilation of what have been written on the camelopardalis from the Antiquity to the $16^{\text {th }}$ Century, confronting Classical and Medieval sources, an selecting up-to-date information in his contemporaries' works. He was [579] the first zoohistorian to oppose different views about the translation of the zemer in the Deuteronomy book, using medieval Jewish scholars' works, and giving his personal view (that the zemer 
is a giraffe), in opposition of many commentators and translators of the Bible, among them Luther.

Gessner's large compilation of sources about the giraffe doesn't neglect medieval authors. The information borrowed from Nicephorus Callisthus, Marco Polo, Niccola da Poggibonsi, Albertus Magnus, Vincent of Beauvais are chosen with great care, giving new descriptions and new facts (naming, geographic origin) about the animal, complementary to the Classical sources, and even to Gessner's contemporaries.

Gessner consciously adds new information to the second edition of the Icones animalium, that will be inserted in the second post mortem edition of the Historia animalium, quoting some contemporary authors, Scaliger, Paolo Giovio and Leo Africanus, coming with Nicephorus Callisthus.

Gessner's major concern about the quality of the illustrations of the animals was betrayed by some mistake in the choice of the giraffe woodcut. Initially taken from the Viaggio da Venezia al san Sepulchro, the image was finally copied from a woodcut by E. Reuwich, which illustrated the Travels of Bernhard von Breydenbach to the Holy Land. There was a confusion between two pilgrimage travelogues, as Breydenbach picture grouping various animal of the Holy land and Egypt has been used in Gessner's Historia animalium, as in various books in the $16^{\text {th }}$ Century. This mistake will be still present in the second editions of the Icones and the Historia animalium, but with the addition of a new and contemporary image by Melchior Lorichs, printed shortly after its realization in Constantinople at the end of the 1550's. The Lorichs woodcut will definitively replace the "original" picture from the Viaggio, which has never been printed in Gessner's edition. The major contribution of this article is to shed light on this "ghost picture", seen and chosen by Gessner.

\section{Image captions}

Fig. 1: "Camelopardalis”, Konrad Gessner, Historia animalium, Zürich, Froschauer, 1551. Lyon, BM, res. 31356, p. 160. Photo: Th. Buquet.

Fig. 2: "Camelopardalis", Konrad Gessner, Icones animalium quadrupedum viviparorum et oviparorum. Zürich, Froschauer, 1560. Zentralbibliothek Zürich NNN 44 F, p. 125.

Fig. 3 : "Surnappa", drawing by Melchior Lorichs, Nuremberg, Hans Adam, 1559. Zentralbibliothek Zürich, Graphische Sammlung, PAS 11 5/8.

Fig. 4: "Camelopardalis", Konrad Gessner, Icones animalium quadrupedum viviparorum et oviparorum. Zürich, Froschauer, 1560. Zentralbibliothek Zürich NNN 44 F, p. 42.

Fig. 5: "Animals of the Holy Land", Bernhard von Breydenbach, Peregrinationes in Terram Sanctam (dutch version), Utrecht, E. Reuwich, 1488. Den Haag, KB 168 B 8, sign. r 7.

Fig. 6: "Giraffa", Viaggio da Venetia al Santo Sepolcro, Venezia, Alessandro de Vecchi, 1606, sign. I a.

Fig. 7: "Babuino, Cocodrillo, Lioncorno \& salamandra", Viaggio da Ventia al Santo Sepolcro, Venezia, Alessandro de Vecchi, 1606, sign. D c.

Fig. 8: “Camelopardalis", Petrus Candidus, De animantium naturis (15 ${ }^{\text {th }}$ C.), Biblioteca apostolica Vaticana, Urb. Lat. 276, f. 14v. Painting by Teodoro Ghisi, end of the $16^{\text {th }}$ C.

Fig. 9: "Oraflus-girafa", Petrus Candidus, De animantium naturis (15 ${ }^{\text {th }}$ C.), Biblioteca apostolica Vaticana, Urb. Lat. 276, f. 46v. Painting by Teodoro Ghisi, end of the $16^{\text {th }}$ C. 


\section{Bibliography}

\section{Manuscripts}

Petrus Candidus Decembrio, De animantium naturis, Biblioteca apostolica Vaticana, Urb. Lat. 276. http://digi.vatlib.it/view/MSS Urb.lat.276/0001

\section{Books and articles}

Albert le Grand: De animalibus libri XXVI : nach der Cölner Urschrift, edited by Hermann Stadler. 2 vols. Beiträge zur Geschichte der Philosophie des Mittelalters 15-16. Münster 1916.

Aneau, Barthélemy: Décades de la description, forme et vertu naturelle des animaulx.... Lyon 1549. http://gallica.bnf.fr/ark:/12148/btv1b86082971

Arnold von Harff: The Pilgrimage of Arnold Von Harff, Knight, from Cologne, through Italy, Syria, Egypt, Arabia, Ethiopia, Nubia, Palestine, Turkey, France and Spain, Which he Accomplished in the Years 1496 to 1499, edited by Malcolm Letts. Hakluyt Society, $2^{\text {nd }}$ series 94. London 1946.

Barbaro, Josafa, and Ambrogio Contarini: Travels to Tana and Persia, translated by William Thomas and S. A. Roy. London 1873.

Bartholomeus Anglicus: De proprietatibus rerum. Köln 1483.

Belon, Pierre: Les observations de plusieurs singularitez et choses mémorables, trouvées en Grèce, Asie, Judée, Égypte, Arabie et autres pays estranges rédigés en trois livres. Paris 1553.

Belon, Pierre: Voyage en Égypte (1547), edited by Grégoire Holtz. Cadratin. Paris 2004.

Bersuire, Pierre: Opera omnia totam S. Scripturæ, morum, naturæ historiam complectentia, t. 1 . Antwerp 1609.

Bochart, Samuel: Hierozoïcon, sive Bipertitum opus de animalibus Sacrae Scripturae. Pars prior agit libris quatuor de animalibus in genere et de quadrupedibus, viviparis et oviparis. Pars posterior agit libris sex de avibus, serpentibus, insectis, aquaticis et fabulosis animalibus, cum indice septuplici... 2 vols. London 1663.

Bochart, Samuel: Hierozoicon, sive De animalibus S. Scripturae, vol. 2, edited by Ernst Friedrich Carl Rosenmüller. Leipzig. 1794.

Boltz, William G: Leonardo Olschski and Marco Polo's Asia (with an Etymological Excursus on Giraffe), in: Romance Philology 23/1 (1969), pp. 1-16.

Breydenbach, Bernhard von: Peregrinationes sin Terram Sanctam. Mainz 1486.

Buquet, Thierry: Animalia extranea et stupenda ad videndum. Describing and Naming Exotic Beasts in Cairo Sultan's Menagerie, in: Monica A. Walker Vadillo, Francisco de Asís García García, María Victoria Chico Picaza (eds): Animals and the Otherness in the Middle Ages. Perspectives across disciplines. British Archaeological Reports, International Series 2500. Oxford 2013, pp. 25-34.

Buquet, Thierry: La belle captive. La girafe dans les ménageries princières au Moyen Âge, in: Corinne Beck, Fabrice Guizard (eds): La bête captive au Moyen Âge et à l'époque moderne. Encrage université. Amiens 2012, pp. 65-90.

Buquet, Thierry: La girafe, belle inconnue des bibles médiévales. Camelopardalis : un animal philologique, in: Anthropozoologica 43/2 (2008), pp. 47-68.

Buquet, Thierry: Pourquoi la Bible des Septante a-t-elle traduit le zemer du Deutéronome en kamelopardalis ? Réflexions sur le statut symbolique et alimentaire de la girafe, in: Anthropozoologica 41/1 (2006), pp. 7-25.

Cuttler, Charles D.: Exotics in Post-Medieval European Art: Giraffes and Centaurs, in: Artibus et Historiae 12/23 (1991), pp. 161-179.

Dittrich, Lothar; Sigrid Dittrich; Ingrid Faust: Das Bild der Giraffe. Veröffentlichtung des Zoos Hannover. Hannover 1993.

Donati, Lamberto: La giraffa (Iter iconographicum. Cita del Vaticano. Bibliotheca), in: Maso Finiguerra. Rivista della Stampa Incisa e del libro illustrato 3 (1938), pp. 247-268. 
Ducos, Joëlle (ed.): Encyclopédie médiévale et langues européennes. Réception et diffusion du De proprietatibus rerum de Barthélemy l'Anglais dans les langues vernaculaires. Colloques, congrès et conférences-Sciences du langage, histoire de la langue et des dictionnaires 12. Paris 2014.

Fischer, Erik: Von weiteren Kopien nach Melchior Lorck nebst einem Exkurs über die Protoikonographie der Giraffe, in: Nordelbingen 43 (1974), pp. 81-92.

Gatier, Pierre-Louis: Des girafes pour l'empereur, in: Topoi : Orient-Occident 6/2 (1996), pp. 903-941.

Gatier, Pierre-Louis: Les girafes de Gaza, in: Catherine Saliou (ed): Gaza dans l'Antiquité tardive: histoire, rhétorique, archéologie: actes du colloque international de Poitiers (6-7 mai 2004). Salerno 2005, pp. 75-92.

Gesner, Conrad: Historia animalium. Lib. I. de quadrupedibus viviparis. Zürich 1551. http://dx.doi.org/10.3931/e-rara-1927.

Gesner, Conrad: Historia animalium. Lib. I. de quadrupedibus viviparis. Frankfurt 1620.

Gesner, Conrad: Icones animalium quadrupedum viviparorum et oviparorum. Zürich 1560. http://dx.doi.org/10.3931/e-rara-1668.

Glardon, Philippe: L'histoire naturelle au XVI ${ }^{\mathrm{e}}$ siècle : introduction, étude et édition critique de La nature et diversité des poissons de Pierre Belon (1555). Travaux d'humanisme et renaissance 483. Geneva 2011.

Herr, Michael: Das neue Tier- und Arzneibuch des Doktor Michael Herr (1546), Edited by Gerhard E. Sollbach. Würzburg 1994.

Joost-Gaugier, Christiane L.: Lorenzo the Magnificent and the Giraffe as a Symbol of Power, in: Artibus et Historiae 8/16 (1987), pp. 91-99.

Kusukawa, Sachiko: The sources of Gessner's pictures for the Historia animalium, in: Annals of Science 67/3 (2010), pp. 303-328.

Leu, Urs B., Raffael Keller, and Sandra Weidmann: Conrad Gessner's private library. History of science and medicine library 5. Leiden-Boston 2008.

Leu, Urs Bernhard: Die Giraffe von Melchior Lorichs 1559. Von Konstantinopel über Nürnberg und Zürich nach Peking, in: Zentralbibliothek Zürich. Alte und neue Schätze, edited by Alfred Cattani, Michael Kotrba, and Agnes Rutz. Zürich 1993, pp. 70-73, notes pp. 198-198.

Luther, Martin: Das Alte Testament deutsch. Basel 1523. http://dx.doi.org/10.3931/erara-648.

Meyer, Heinz: Die Enzyklopädie des Bartholomaeus Anglicus. Untersuchungen zur Überlieferungs-und Rezeptionsgeschichte von 'De proprietatibus rerum'. Müntersche Mittelalter-Schriften 77. München 2000.

Moore, Kathryn Blair: The Disappearance of an Author and the Emergence of a Genre: Niccolò da Poggibonsi and Pilgrimage Guidebooks between Manuscript and Print, in: Renaissance Quarterly 66/2 (2013), pp. 357-411.

Mornando, Francesco: Pestilence, Apostasy, and Heresy in Seventeenth-Century Rome: Deciphering Michael Sweerts' Plague in an Ancient City, in: Francesco Mornando, Thomas Worcester (eds): Piety and Plague: From Byzantium to the Baroque. Sixteenth Century Essays and Studies. Kirksville, MO 2007, pp. 237-271.

Munster, Sebastian: Biblia Hebraica, latine planeque... Basel 1546.

Nardone, Jean-Luc (ed.): La représentation de Jérusalem et de la Terre Sainte dans les récits de pélerins européens au XVI ${ }^{\mathrm{e}}$ siècle. Études et essais sur la Renaissance 75. Paris 2007.

Nardone, Jean-Luc: Péripéties éditoriales d'un 'best-seller' du XVI ${ }^{\mathrm{e}}$ siècle : le guide de pèlerinage de Venise au Saint-Sépulcre et au mont Sinaï, in: Littératures 72 (2015), pp. 217-228.

Nardone, Jean-Luc: Sept planches d'iconographie animalière dans le Viaggio da Venetia al santo Sepulcro (1519), in Italies. Littérature - Civilisation - Société 10 (2006), p. 37-55. DOI: 10.4000/italies.709. http://italies.revues.org/709

Nicephorus Callistus Xanthopulus: Ecclesiasticae historiae libri decem et octo, Edited by Johannes Langus. Basel 1553.

Pellikan, Konrad: Biblia sacrosancta Testamenti Veteris \& Novi. Zürich 1544. https://doi.org/10.3931/e-rara-5035. 
Pellikan, Konrad: Commentarum Bibliorum. I. In Pentateuchum sive quinque libros Mosis, nempe Genesim, Exodum, Leviticum, Numeros, Deuteronomium.... Zürich 1582. http://dx.doi.org/10.3931/e-rara-26284.

Pinon, Laurent: Conrad Gessner and the Historical Depth of Renaissance Natural History, in: Gianna Pomata, Nancy G. Siraisi (eds): Historia: Empiricism and Erudition in Early Modern Europe. Cambridge (Mass.) London 2005, pp. 241-267.

Pliny: Natural History. III, Libri VIII-XI, edited by H. Rackham. Loeb Classical Library 353. London-Cambridge (Ma) 1940.

Poggibonsi, Fra Niccola da: Libro d'Oltremare, edited by B. Bagati. Pubblicazioni dello Studium Biblicum Franciscanum 2. Jerusalem 1945.

Poliziano, Angelo: Liber miscellaneorum, in: Opera omnia, edited by Ida Maier, vol. 1. Monumenta politica philosophica humanistica rariora. Series 1, 16. Torino 1971.

Pyle, Cynthia M.: Das Tierbuch des Petrus Candidus. Codex Urbinas Latinus 276: eine Einführung. Zürich 1984.

Pyle, Cynthia M.: The Art and Science of Renaissance Natural History Thomas of Canllmpre, Pier Candido Decembrio, Conrad Gessner, and Teodoro Ghisi in Vallcan Library Ms Urb. Lat. 276, in: Viator 27 (1996), p. 265-321.

Schmutz, Hans-Konrad: Gessners Tierbuch - zur Historia animalium, in: Urs B. Leu, Mylène Ruoss (eds) Conrad Gessner 1516-2016. Facetten eines Universums, pp. 129-154. NZZ libro. Zürich 2016.

Thomas de Cantimpré: Liber de natura rerum, edited by Helmut Boese. Berlin-New York 1973.

Thomas de Cantimpré: Liber de naturis rerum. Redaktion III (Thomas III), edited by Konrad Vollmann. Eichstät 1992.

Van Den Abeele, Baudouin: Diffusion et avatars d'une encyclopédie: le Liber de natura rerum de Thomas de Cantimpré, in: Baudouin Van Den Abeele, Godefroid de Callataÿ (eds): Une lumière venue d'ailleurs. Héritages et ouvertures dans les encyclopédies d'Orient ét d'Occident au Moyen Âge. Actes du colloque de Louvainla-Neuve, 19-21 mai 2005. Reminisciences 9. Turnhout 2008, pp. 141-176.

Vincent de Beauvais: Speculum naturale. Strasbourg 1476. http://digital.ub.uniduesseldorf.de/ihd/content/pageview/1350052.

Vincent de Beauvais, , Speculum quadruplex sive speculum maius. Douai 1624.

Viaggio da Venetia al sancto sepolchro et al monte Synai. Venezia 1519,

Viaggio da Venetia al Santo Sepolcro, et al monte Sinai. Venezia 1606. http://archive.org/details/viaggiodavenetia00bian. 